\title{
Optimizing the Risk-preparedness and Disaster Management Systems of all World Heritage Sites by Exploiting HPWS and Conform to the UNESCO Guidelines
}

\author{
Mehdi S. Kaddory Al-Zubaidy* \\ Faculty of Architecture and Environmental Design, (IIUM), Gombak, Malaysia \\ *Corresponding author: mkaddory@yahoo.com
}

Received November 05, 2014; Revised November 24, 2014; Accepted November 26, 2014

\begin{abstract}
The paper examines the possible efficacy of HPWS (High-Performance Work System) in optimizing the risk-preparedness and disaster management of the World Heritage Sites (WHS), using Alhambra Palace, Spain, as the test site. Most of the WHSs are vulnerable to various types of risks, and the UNESCO has set a stringent standard for their maintenance, failing which any WHS will lose its title. The paper has a goal of finding a common risk-preparedness and disaster management solution that would enable all WHSs to conform to the maintenance standard set by the UNESCO. A test survey conducted on Alhambra site WHS which chosen as a case study of World Heritage Sites under UNESCO, the feedback shown that it is possible to exploit HPWS to optimize the riskpreparedness and disaster management systems of all World Heritage Sites and conform to the UNESCO Guidelines.
\end{abstract}

Keywords: World Heritage Sites (WHS), risk-preparedness, UNESCO, disaster management, HPWS

Cite This Article: Mehdi S. Kaddory Al-Zubaidy, “Optimizing the Risk-preparedness and Disaster Management Systems of all World Heritage Sites by Exploiting HPWS and Conform to the UNESCO Guidelines." American Journal of Civil Engineering and Architecture, vol. 2, no. 6 (2014): 177-185. doi: 10.12691/ajcea-2-6-1.

\section{Introduction}

The issue of disaster management plays a vital role in the management of the World Heritage Sites, since all of them contain several unique elements that are vulnerable on many accounts. For example, most of the heritage architectures belong to earlier times and have become fragile due to environmental and man-made impacts on them over the years (James, 2008). Similarly, the natural sites contain several species that are facing extinction due to the same reason. In fact, the fear of losing those valuable assets of the globe, UNESCO passed its charter on $16^{\text {th }}$ November 1972 in its $17^{\text {th }}$ Convention where it resolved to identify the natural and heritage sites of the world and declare them as the World Heritage Site (henceforth will be mentioned as WHS) [1]. The organization laid down a general framework for protection of WHSs against disasters. Accordingly, the UNESCO has so far inscribed 936 properties as the WHS, which include 725 cultural, 183 natural, and 28 mixed properties across 153 countries [2].

A major challenge facing WHSs is climate. Change in climate has an impact that ranges from social to cultural and physical aspects [3]. With regards to heritage sites, a majority of biomes may be adversely affected by changes in climate. A number of management responses are required at local and national levels to address climate change and its impacts on heritage sites. In addition, according to George [4], natural disasters like the latest incidents of Tsunami and other human activities like war are a big threat to WHSs and should be addressed urgently.

Therefore, the above state of affairs strongly suggests the incorporation of Strategic Human Resource Management (SHRM) for achieving quality risk preparedness and disaster management of the WHSs [5]. At least, two reasons back the aforementioned suggestion. First, the jobs involved in risk preparedness and disaster management of WHSs require multidimensional competences ranging from expertise to total employee commitment. Second, each WHS requires conforming to the maintenance standard set by the UNESCO, failing which it would lose the WHS status from that site [6]. This study, therefore, investigates on the viability of High-Performance Work System (HPWS), a SHRM application tool, in optimizing the disaster management systems in all WHSs and enabling them to conform to the maintenance standard of a WHS set by the UNESCO.

This study is novel in the sense that it is a pioneer research regarding the use of HPWS to improve risk preparedness of WHSs. According to Stovel [7], the main methods that have been used to prepare for risk and disaster in the past are narrowed down to specific risk i.e. property-specific strategies. For instance, preparedness against disasters such as fire is delegated to the country's 
fire department and is not largely intertwined to the workers in the WHS. These past methods of singling out potential risks and disasters and leaving them to professionals, who may not be direct employees of the WHS, had many loop holes [8]. For instance, the bodies engaged in times of risks may not have the long term goals of WHS hence may act in ignorance of such goals and cause damage to the WHS. This study will seek to justify the need for HPWS in risk and disaster preparedness in WHS which is an improvement over the traditional property-specific approach.

\section{Significance of Risk Preparedness to WHSs}

There are at least 30 recorded instances world-famous knowledge repositories were destroyed by foreign invaders since second century B.C [9]; while there are uncountable accounts of heritage structures succumbing to natural disasters, besides the instances of human encroachment destroyed the biodiversity of natural places. The above instances clearly show that all WHS sites are vulnerable to either natural or man-made disasters. Otherwise, the UNESCO could inscribe several great heritage structures such as the 2000-year-old Bam citadel in southeastern Iran that was destroyed by an earthquake in late 2003 or the Nalanda University of India that was destroyed by invading warriors [10].

The International Centre for the Study of Preservation and Restoration (ICCROM) identifies the riskmanagement issue as a crucial factor in managing heritage sites, and it presents a comprehensive guideline for local and national authorities in countries and regions on risk preparedness for cultural heritage in collaboration with the International Committee of the Blue Shield (ICBS). The above guideline summarizes the basic principles of risk preparedness for cultural heritage in two brief points:

1. The management should integrate the cultural heritage assets into existing disaster management plans;

2. The management should adopt preventive approaches to improve or maintain the condition of such heritage assets to ensure the survival of the heritage and its significant messages during and after natural disasters [11].

There are other initiatives too. The Swiss cultural heritage authorities have implemented an integrative disaster management plan to obtain a systematic approach in managing their heritage structure. Under their framework of risk management, the decision-making processes of preventive conservation involve four recognized steps to realize risk management approach to preservation issues, and they are:

1. Underpinning all risks to heritage sites;

2. Assessing the magnitude of each of such risks;

3. Identifying possible mitigation strategies; and

4. Evaluating the costs and benefits associated with each strategy [12].

The government of Turkey also has taken serious precautionary measures to protect Istanbul after experiencing a series of earthquakes in 1999 that took away more than 17,000 lives and caused a $6 \%$ loss in its GNP [13].

The situations reviewed above highlights several points, such as risk-preparedness is an extremely important factor in managing the WHSs, and that requires expertise, dedication, and appropriate strategies. These factors, thus naturally command application of SHRM to equip any WHS disaster management team, since SHRM contains certain modules that aim to optimize the organizational performance by identifying the organizational areas that need a reformation and providing appropriate fits for them [14]. The gravity of the tasks involved in any WHS management also corroborates the above proposition.

\subsection{Tasks Involved in WHS Disaster Management}

The risk factors associated with heritage sites emanate from natural hazards of various types and man-made crisis factors. The UNESCO/WHC [15] has published a special manual on managing disaster risks, where it has underpinned seven types of common hazards that may lead to a disaster:

1. Meteorological: Hurricanes, tornadoes, heat-waves, lightning, fire;

2. Hydrological: Floods, flash-floods, tsunamis;

3. Geological: Volcanoes, earthquakes, mass movement (falls, slides, slumps);

4. Astrophysical: Meteorites;

5. Biological: Epidemics, pests;

6. Human-induced: Armed conflict, fire, pollution, infrastructure failure or collapse, civil unrest and terrorism;

7. Climate change: Increased storm frequency and severity, glacial lake outburst floods.

Apart from that UNESCO also cautions that disastrous situations turn even more complex when human-induced hazards combine with natural hazards Table 1.

\begin{tabular}{|c|c|c|c|}
\hline Type & Natural & Human-induced & Indirect/Secondary \\
\hline Meteorological & $\begin{array}{l}\text { Hurricane; Lightning; Heavy } \\
\text { precipitation. }\end{array}$ & & $\begin{array}{l}\text { Flooding (coastal/rivers); } \\
\text { Fire; Mass movement. }\end{array}$ \\
\hline $\begin{array}{l}\text { Hydrological (caused by high } \\
\text { rainfall) }\end{array}$ & $\begin{array}{l}\text { Replace, with, Flash flood; } \\
\text { Landslide/volcanic ash/lava/ice; } \\
\text { damming of a river; Tsunami. }\end{array}$ & $\begin{array}{l}\text { Hydrological infra-structure failure (dams, } \\
\text { levees, reservoirs, drainage systems); } \\
\text { Coastal protection failure (sea walls). }\end{array}$ & $\begin{array}{l}\text { Disease; epidemic; } \\
\text { Pollution. }\end{array}$ \\
\hline Volcanic & $\begin{array}{l}\text { Lava flows; Pyroclastic flows; Ash } \\
\text { and block falls; Gases; }\end{array}$ & Mining-induced (e.g. mud volcano). & $\begin{array}{c}\text { Lahars (mudflows); } \\
\text { Landslides; Tsunami; Fire. }\end{array}$ \\
\hline Seismic & $\begin{array}{c}\text { Faulting; Transient shaking; } \\
\text { Permanent deformation (e.g. folds); } \\
\text { Induced movement (liquefaction and } \\
\text { mass movement). }\end{array}$ & $\begin{array}{l}\text { Dam-and-reservoir-induced mass } \\
\text { movement; Mining-induced; } \\
\text { Explosion/nuclear induced. }\end{array}$ & $\begin{array}{l}\text { Mass movement; Fire; } \\
\text { Flood; }\end{array}$ \\
\hline $\begin{array}{l}\text { Mass movement (of snow, ice, } \\
\text { rock, soil mud, etc.) (induced } \\
\text { by slow-acting erosion or one } \\
\text { of the above) }\end{array}$ & Falls; Slumps; Slides; Flows. & $\begin{array}{l}\text { Unstable mining/construction waste; Spoil } \\
\text { heaps. }\end{array}$ & \\
\hline
\end{tabular}


Table 2. Some examples of man-made and natural disasters [16,17]

\begin{tabular}{|c|c|c|}
\hline Category of Disasters & Type & Affected Property \\
\hline Man-made & Armed Conflicts & $\begin{array}{l}\text { Heavily damaged the Temple of the Tooth Relic in Kandy (Sri Lanka) in 1998; } \\
\text { Destroyed the Bamiyan Buddhas in Afghanistan in 2001; } \\
\text { Gulf-war destroyed many heritage buildings in Afghanistan and Iraq, besides heavily } \\
\text { damaging natural environment of the region through oil spill. }\end{array}$ \\
\hline \multirow{6}{*}{ Natural } & Fire & Destroyed the Old Town of Edinburgh in 2002 \\
\hline & Earthquake & $\begin{array}{l}\text { Razed the Citadel of Bam (Iran) in } 2003 \\
\text { Prambanan Temple Compounds (Indonesia) in } 2006 .\end{array}$ \\
\hline & Hurricane Sidr cycle & $\begin{array}{l}\text { Heavily damaged the mangrove forest and wildlife in the coastal areas of Bangladesh and } \\
\text { India }\end{array}$ \\
\hline & Hurricane Sandy & Damaged the natural wealth of the US to a great extent. \\
\hline & $\begin{array}{l}\text { Change caused by El Niño } \\
\text { in the climatic cycles }\end{array}$ & $\begin{array}{l}\text { Affected the sea levels and consequently storm and floods are gradually becoming common } \\
\text { features in many parts of the world. }\end{array}$ \\
\hline & Climatic change & $\begin{array}{l}\text { Increased the soil moisture that increased the vulnerability of the archaeological remains to } \\
\text { natural hazards such as earthquakes and floods. Much of Haiti's heritage was damaged or } \\
\text { destroyed in the } 2010 \text { Haiti earthquake }\end{array}$ \\
\hline Mixed Effect & Outbreak of disease & Damaged butterfly population in Mexico \\
\hline
\end{tabular}

Any WHS can be exposed to one or more types of the hazards mentioned above. A few examples would be appropriate here Table 2.

Another important fact is that disasters and hazards pose risks not only to the overall physical attributes of any WHS, but also pose risks to the lives of visitors, WHS management staff, and the local communities next to any WHS site. Generally, the majority of the population growth around any WHS is higher than the average for the rural regions in that country [17], which supports the assumption that more people might be affected by a hazard, resulting in a high disaster risk. Thus, it can also be surmised that the occurrence of disasters puts all WHS management authorities under great pressure to manage the situations, which in turn commands comprehensive risk-preparedness.

Therefore, one can see that the jobs involved in risk preparedness and disaster management in these cases require multidimensional competence, and for that matter, the employees engaged in disaster management of the WHSs require appropriate training and an attitude to serve 24/7 under any circumstance [18]. Since a disaster management team under the management of any WHS is a part of the whole team, the issue of team synergy becomes extremely crucial to achieve an optimized management system that would be able to successfully run its disaster management system and conform to the WHS maintenance standards set by the UNESCO. For that matter, the management requires aligning a number of factors to its advantage, such as employee expertise, employee attitude, cross-cultural communication, which are dependent on several management policies such as recruitment, reward system, workplace ambience, training, and empowerment of the employees. Since HPWS promises to improve the above areas of policy-making, it would be pertinent to review the mechanism of HPWS.

\section{HPWS as a SHRM Application Tool}

The concept of HPWS emerged as a management solution in the late $20^{\text {th }}$ century, when the US manufacturing industry was experiencing a severe slump due to the increased global competition spearheaded by China and Japan. It is essentially a humanistic approach that aligns with the excellent theory of leadership and employee-centric approach. It aims to identify and exploit the intangible organizational assets within the employees, and for that matter, it applies many HRM principles, such as synchronizing the individual employee goals with the goals of the organization, equipping the employees with tacit knowledge for deciphering the messages of change, and to prepare them for managing the same. Boxall and Macky $[19,20]$ frames two issues that HPWS considers most important:

- Rectifying the situations that show discord between HR systems and the employees due to the changed context of competition;

- Establishing a positive correlation between HR systems and organizational performance.

Initially, HPWS operated with three modules of operations such as involvement, training, and incentives, before adding support technology as its fourth module to make it fully compliant to the demands of the modern workplaces. The following diagram Figure 1. frames its basic structure:

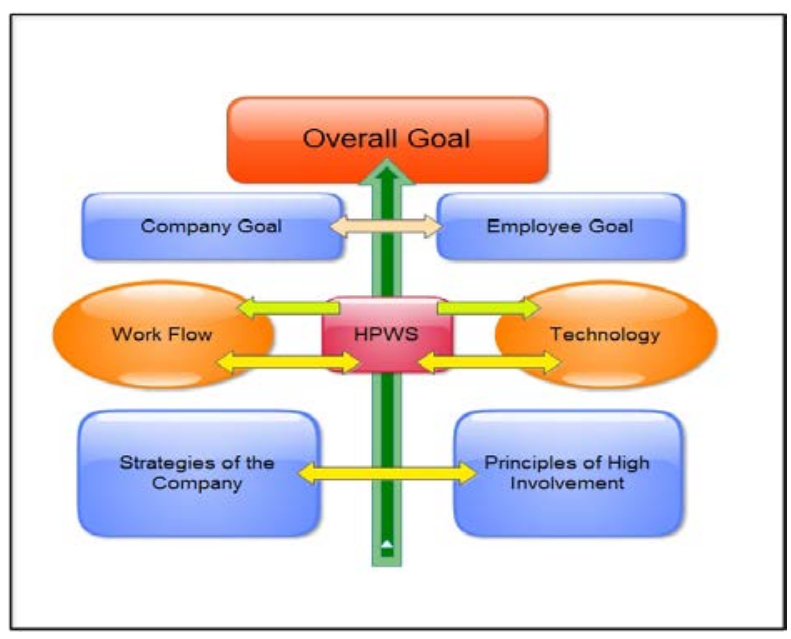

Figure 1. General structure of HPWS

\subsection{Modules of HPWS}

The first module of HPWS is Involvement, which aims to fulfil its objective of facilitating increased employee participation in the organizational decision making processes [21]. For that matter, it sets up systems that enable constant information-sharing among the members of the organization. The HPWS takes extreme care to convince the employees regarding its employee-centric 
approach and its motto of becoming a part of the newfound business outlook that prioritizes fostering human capital to earn rich dividend for the organization [22]. This module eventually initiates the desired transformation process by infusing a culture of information-sharing and exploiting the information for the benefit of the organization [23].

The second module of HPWS is Training, which aims to develop the knowledge, skill base, and expertise of the employees in their respective operational fields. Here also it resorts to incremental change process to create and sustain the culture of indulging in 'on-site' or 'real-time' training. For that matter, it uses customized training modules and applies innovative methods to evoke the creativity and the spirit of a challenge in the employees, and encourage them to apply the same in their respective working spheres. Eventually, through this module the HPWS enriches the organizational knowledge bank and encourages the organization to exploit that and optimize its performance. To ensure a smooth functioning of this module, the HPWS frames the scopes of the current job sets as well as the emerging jobs in a particular sector and tries to align them with the existing knowledge base of the organization.

The third module of HPWS is Rewards or Incentives, which aims to align the individual employee goals with the goal of the organization. Accordingly, it adopts a systematic approach to exploit the reward and incentive system toward optimizing the employee performance. In the process, it works out the utility value of the existing rewards system and strengthens the connection between rewards and employee performance.

The fourth module is Technology, which aims to exploit the advantage of modern technology to improve the functioning of the various organizational systems. Accordingly, it measures the existing knowledge and skill base of the employees to learn about the individual requirements of the employees and to find appropriate technology to meet such requirements. In all, HPWS wants to create an egalitarian and enthusiastic workplace with able and dedicated employees [24]. The Theoretical objective of HPWS can be framed like Figure 2.

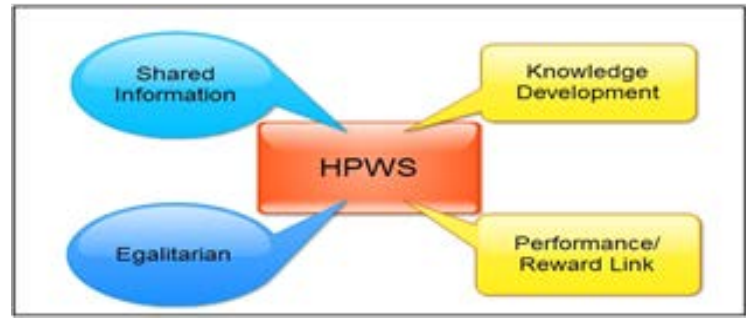

Figure 2. Theoretical Objective of HPWS

Following the basic principles of HRM, the HPWS facilitates the implementation of all HR policies and procedures to meet the various needs of the organization. For that matter, it works on two layers, such as internal and external layers and to achieve the internal fit and external fit as shown in Figure 3.

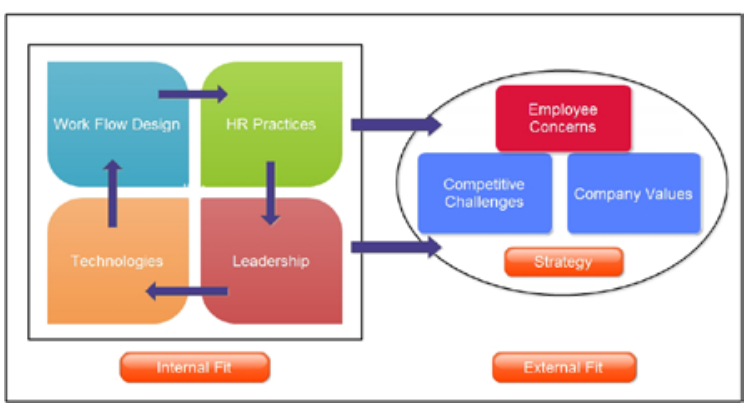

Figure 3. Internal \& External Fit

The HPWS tries to frame all organizational affairs and evaluate them for systematically eliminating the barriers to desired level of performance by developing the positive factors of organizational growth. Boxall and Macky [19] identify three drivers of its strategy such as:

1. Competitive Challenges.

2. Company Values.

3. Employee Concerns.

To obtain the internal and external fit, HPWS conducts SWOT and PEST analyses to identify the areas requiring fit and then concentrates on finding ways to eliminate the barriers and improvise the facilitators of optimized internal coordination and a favorable external condition [25].

Table 3. HPWS plan sheet, Adapted from Boxall and Macky [19]

\begin{tabular}{|c|c|c|c|c|}
\hline The organization & \multicolumn{4}{|c|}{ Parameters of HPWS } \\
\hline Components & Shared Information & Knowledge Development & Performance-Reward Link & Egalitarianism \\
\hline \multicolumn{5}{|l|}{ Work Flow } \\
\hline \multirow{2}{*}{$\begin{array}{l}\text { Self-managed teams } \\
\text { Supervised Teams }\end{array}$} & * & & & * \\
\hline & * & * & & * \\
\hline \multirow{3}{*}{$\begin{array}{c}\text { Staffing } \\
\text { Selective recruiting } \\
\text { Team decision making }\end{array}$} & & & & \\
\hline & & * & * & \\
\hline & * & * & & * \\
\hline \multirow{5}{*}{$\begin{array}{c}\text { Training } \\
\text { Broad skills } \\
\text { Cross-training } \\
\text { Problem solving } \\
\text { Team training }\end{array}$} & & & & \\
\hline & * & * & & \\
\hline & * & * & & * \\
\hline & * & * & & * \\
\hline & * & * & & * \\
\hline \multirow{5}{*}{$\begin{array}{l}\text { Compensation } \\
\text { Incentive } \\
\text { Gain sharing } \\
\text { Profit-sharing } \\
\text { Skill-based pay }\end{array}$} & & & & \\
\hline & & & * & * \\
\hline & * & * & * & * \\
\hline & * & * & * & * \\
\hline & $*$ & * & * & * \\
\hline \multicolumn{5}{|l|}{ Leadership } \\
\hline \multirow{2}{*}{$\begin{array}{c}\text { Few layers } \\
\text { Coaching/facilitators }\end{array}$} & * & * & * & * \\
\hline & * & & & * \\
\hline \multirow{3}{*}{$\begin{array}{c}\text { Technologies } \\
\text { HRS } \\
\text { Communications }\end{array}$} & & & & \\
\hline & * & & & \\
\hline & * & * & & * \\
\hline
\end{tabular}


Upon receiving the detailed information from the analyses, HPWS prepares its plan-sheet for action, which contains the zones requiring fits, along with their level of priority. An imaginary plan sheet of HPWS looks like Table 3.

The above plan-sheet generates several subsets of the plan-sheets that contain more specific types of organizational needs in detail. For example, HPWS may find it is important to intrinsically motivate an employee, and accordingly, it may formulate a special training plan to do the same. Through such a strategy, HPWS creates a positive impact on the vital organizational issues such as workflow, Staffing, Training, Compensation, Leadership, and Technology.

For example, HPWS uses one or the other attitude building frameworks based on the requirements of the organization to ensure that all categories of staff uniformly carry the workflow of their respective departments by exploiting team communication and knowledge-sharing processes.

Similarly, in the case of staffing it incorporates knowledge development by recruiting experts in such areas through proper screening, making it sure that the new employee possesses all skills and expertise to meet the job requirement and an attitude to align individual vision with the organizational vision. Accordingly, it creates a demand forecast plan along with justification notes against all recommendations regarding recruitment. Next, it conducts a systematic analysis of the positions need to be filled/modified on the basis of the organizational requirement and creates a detailed job description for each such post.

Regarding training, HPWS identifies the areas that require special training, besides stressing on knowledge development processes and team training in general. It takes such two-tier approach with two objectives, such as to equip the organization with special knowledge and expertise and to keep the organization free from interdepartment miscommunication, emergence of disputes, accidents, or production problems due to lack of knowledge and lack of desired organizational behavior. Altogether, it aims to enhance the cognitive and emotional capacities of the employees, and for that matter, it exploits one or the other theoretical frameworks such as Gardner's [26] Multiple Intelligence Theory or Goleman's [27,28] Emotional Intelligence Theory.

Regarding compensation, HPWS first gathers a clear understanding about the state of employee satisfaction regarding the existing rewards and compensation system and whether the existing system conforms to the industrial norms. Alongside it also checks whether there is a clear policy of individual assessment. Accordingly, it works on all the above areas, and incorporates the inputs in the reward and incentive system to make it a fair system comprising of justified incentive, gain sharing, profitsharing and skill-based pay.

Regarding the leadership issue, HPWS tries to ensure that leadership should be a source of motivation to all employees, and accordingly, it works in tandem with the leadership to initiate all possible processes to motivate the employees. In the process, it tries to create a cumulative motivational force by aligning several appropriate philosophies, such as organizational, leadership, and motivational philosophy, and the philosophy emanating from work-related factors.
Finally, HPWS checks whether the answers to the above queries match with its own philosophy, which is based on the four axioms:

1. An employee is valuable.

2. An employee is rare.

3. An employee is organized.

4. An employee is unparalleled.

The review of HPWS appeared promising under the context, since WHS management almost fully depends on the human capital and therefore, needs extensively managing and fostering the same. However, this study conducted an investigation comprising of theoretical application of HPWS on one of the WHSs and a questionnaire survey comprising of the members associated with that WHS to check whether its approach suites under a WHS setting that contains issues such as employee commitment, knowledge-sharing, cross-cultural competency, risk-preparedness, UNESCO philosophy, marketing philosophy, leadership philosophy, and the philosophy emanating from the site.

\subsection{The Importance of Studying the Applicability of HPWS to Risk Preparedness of WHS}

The success of HPWS is dependent on the type of organization. Different organizations have different variables that require keen consideration before choosing elements of HPWS to be applied. In this light, studying the applicability of HPWS to WHS is important so as to identify the strategy required.

WHSs exist in different geographical locations, hence managed by different countries. This means that the extent of success in management of WHSs is dependent on several variables such as the political state of the country, level of skills of the workers in the country, level of integrity among workers in a given country. For instance, developed countries develop better skilled workers compared to under-developed nations. It is, therefore, expected management of WHSs in developing nations is better. In addition, in countries with political instability and unethical acts such as corruption, workers may breach rules pertaining to the management of the WHSs located in such countries.

Organizations are faced with various competitive challenges such as managing change, adopting global business, developing intellectual capital, embracing technology, responding to clients and containing costs. WHSs are no exception. With this in mind, it is imperative to point out the challenges are unique to various WHSs. Being heritage sites, WHSs have the need to meet short term and long term goals. The implication here is that a HPWS strategy may work in one WHS but fail in another. The different challenges presented by WHSs located and managed in different countries is the main reason for studying the applicability of HPWS to WHS.

\subsection{The Role of Study in Understanding HPWS and WHS}

Studying HPWS and its applicability in WHS will bring out a lot of elements of HPWS and WHS.

The study considers different HPWS elements that can be applied in a WHS. HPWS includes a combination of 
work structures, HR practices, and processes meant to maximize flexibility, commitment, skill and knowledge of employees. Some HR policies are also included in most HPWS. The application of HPWS will follow the underlying principles of High Performance Work Systems. The principles are shared, information, egalitarianism, and performance reward linkage and knowledge development. These principles will be brought out in the study thus aiding in better and deeper understanding of HPWS.

The understanding of HWS will also be enhanced in the study. Before applying a HPWS strategy to a particular HWS, the WHS has to be analyzed critically to identify the most successful elements depending on the challenges faced by the WHS. Since the challenges are dependent on factors like location of the WHS, the significance of the WHS to the world and to the country of location, environmental factors and other externalities, the WHS will be critically analyzed to bring out this knowledge. Therefore, the study will promote a better understanding of both HPWS and WHS.

\section{Viability Test of HPWS as a SHRM Tool for WHSs}

To ascertain the viability of HPWS in optimizing the disaster management systems of the WHSs, the author conducted two tests on Alhambra Palace WHS, Spain, such as assessing its theoretical application and assessing the feedback gathered from the questionnaire survey involving respondents associated with the management of the Alhambra Palace.

\subsection{Reasons behind Choosing Alhambra Palace}

Alhambra Palace is the last and the most splendid example of Arabian palaces that was built in the Moorish regime in Spain around 1234 A.D., and turned into ruins, after which Owen Jones (1809-1879), the London-born versatile architect and designer restored it. This palace contains several fragile artworks that require extreme care to preserve. Apart from that it serves Spain as its symbol of cultural pluralism, as a globally known tourist destination, and as a minefield for the researchers pursuing the science and arts of architecture [29]. Altogether, this Palace contains invaluable architectural elements that integrate mathematics, philosophy, spirituality, and beauty, and because of these qualities, it survived even after the Christians annexed it [30,31]. This Palace is a good example of how a heritage site can contribute to the sustenance and development of the society and civilization, if protected properly. Therefore, the significance of protecting rare and stunning architectural accomplishments of Alhambra makes it an automatic choice for this study.

Apart from the above, the management workforce in Alhambra Palace was cross-cultural, which also enabled this study to check whether HPWS can be effective in a cross-cultural ambience.

\section{Methodology}

This study adopted a mixed method [32,33], where it used the concept emerged from the literature review along with the findings of a questionnaire survey. The mixed method is pragmatic; it is problematic-centered and oriented to real world practice. Using this method, participatory research was carried out by conducting questionnaires to obtain relevant data and project deductions from the real data.

\subsection{Findings of the Theoretical application}

The theoretical application of HPWS included SWOT and PEST analyses of the state of management of the Alhambra Palace to underpin its areas that need external or internal fit and to set the questions on the basis of the same. The above analyses identified eight elements as crucial in optimizing the risk-preparedness and disaster management operations:

1. State of leadership and management

2. State of reward and incentives

3. Job satisfaction

4. Employee commitment

5. Job-specific training

6. Knowledge-sharing

7. Regular appraisal

8. Marketing policy

State of leadership and management, whether strong or weak, was identified as an element of SWOT and PEST analysis because the state influences productivity. A strong management would imply necessary measures are on the ground to ensure high productivity. On the other hand, weak management may result in loss of business and possibly property.

Rewards and incentives to the workers is another factor that influences productivity. Well paid workers are motivated and have the right attitude towards work, hence more productive compared to underpaid workers. For this reason, it is important to analyze the element.

Job satisfaction may be as a result of reward and incentive or individual passions. Workers who are well compensated and are passionate/ love to work in their field are highly productive. However, some workers may be well compensated yet do not love what they do. This can affect productivity and response in times of disaster. Investigating the element is thus important.

Employee commitment is mostly related to job satisfaction, though may be independent as well. Committed employees place duty first. Investigating this element in the SWOT analysis is important to gauge devotion to work; a key to enhanced productivity.

Job specific training is the necessary skills to handle a particular job. This is of particular importance to ensure a professional touch in various fields of work. It is important to investigate whether all persons are qualified to work in their respective fields. Any under qualification would be a weakness.

Knowledge sharing is vital amongst employees to ensure everybody is updated with the latest information. A common weakness is poor communication from top authorities to the workers below the pyramid. Investigating information flow and its ease of flow is therefore important.

Regular appraisal is necessary as a form of appreciation, motivation and recognition by management. Regular appraisals are evidence of a keen management. Investigating this aspect is thus necessary to identify the strength or weakness in management and potential risks. 
The marketing policy adopted by any firm could have a direct effect on the revenue. This is also true for a WHS. A weak policy can be a source of failure and associated risks. Investigating the market policy is, thus vital.

Next, the study followed the application procedures of HPWS by creating plan-sheet and subsequent work-sheets, which theoretically supported the viability of HPWS in optimizing the disaster management systems of the WHSs, as the theoretical application showed that HPWS is capable of fulfilling the above management needs of the Alhambra Palace.

\subsection{Research Question}

The effectiveness of HPWS in risk and disaster management of WHSs will be investigated. The research question will be: is HPWS the best tool for risk and disaster management in WHSs? A survey will be conducted using questionnaire to establish facts and relevant data to investigate the research question. Statistically, the null hypothesis is: HPWS is the best tool for risk and disaster management in WHSs. The alternative hypothesis is: there are tools better than HPWS for risk and disaster management in WHSs. Findings from the questionnaire will back up the hypothesis.

\subsection{Findings from the Questionnaire Survey}

Two main drivers of this survey were,

1. Whether HPWS is appropriate to optimize the disaster management system of the Alhambra Palace;

2. Whether it is viable to implement HPWS in a WHS management site.

Accordingly, the study prepared a questionnaire on the basis of the eight elements identified by the analyses as crucial in optimizing the risk-preparedness and disaster management operations. There were 35 respondents who were associated with the Alhambra Palace management and answered all 30 questions of the questionnaire.

The questions were grouped according to their relation with the above eight elements, and the answers were analyzed.

\section{Result and Analysis}

Table 4. Outcome of the feedback survey

\begin{tabular}{|c|c|c|}
\hline Elements & Feedback & Projected Outlook \\
\hline $\begin{array}{l}\text { 1. State of leadership } \\
\text { and management in } \\
\text { Alhambra Palace: }\end{array}$ & $\begin{array}{l}\text { The state of APWHS management can be improved ( } 89 \%) ; \\
\text { Leadership style is important in APWHS management (92\%); } \\
\text { APWHS is run by traditional (transactional) leadership style } \\
\text { (71\%); } \\
\text { It is not led by transformational /relational leadership style ( } 80 \%) \text {. }\end{array}$ & $\begin{array}{l}\text { APWHS Management needs some solutions; } \\
\text { Leadership issue is important to employees; } \\
\text { APWHS leadership and management is run by } \\
\text { traditional style that requires change; } \\
\text { The employees are not satisfied with the leadership. }\end{array}$ \\
\hline \multicolumn{3}{|c|}{ Outcome 1: HPWS has provisions to fulfill the above needs. } \\
\hline $\begin{array}{l}\text { 2. Preferred } \\
\text { leadership style }\end{array}$ & $66 \%$ did not prefer traditional leadership style. & $\begin{array}{l}\text { APWHS employees prefer Transformational /relational } \\
\text { leadership style. }\end{array}$ \\
\hline \multicolumn{3}{|c|}{ Outcome 2: HPWS has provisions to fulfill the above needs } \\
\hline $\begin{array}{l}\text { 3. Optimising } \\
\text { APWHS Management } \\
\text { through SHRM }\end{array}$ & $\begin{array}{l}\text { There is scope to improve APWHS leadership practice (80\%); } \\
\text { SHRM would be ideal to improve APWHS management (77\%). }\end{array}$ & $\begin{array}{l}\text { Employees prefer application of SHRM in improving } \\
\text { the leadership. }\end{array}$ \\
\hline \multicolumn{3}{|c|}{ Outcome 3: SHRM (HPWS) has high acceptance among employees. } \\
\hline $\begin{array}{l}\text { 4. Job satisfaction and } \\
\text { employee } \\
\text { commitment }\end{array}$ & $\begin{array}{l}\text { Employee safety is crucial (97\%); } \\
\text { Money motivates more than recognition ( } 54 \% \text { undecided); } \\
\text { Recognition is greater motivator ( } 51 \%)\end{array}$ & $\begin{array}{l}\text { Employees require balanced reward system as they find } \\
\text { both extrinsic and intrinsic motivation important to } \\
\text { them. }\end{array}$ \\
\hline \multicolumn{3}{|c|}{ Outcome 4: HPWS has a clear strategy of creating balanced reward systems. } \\
\hline $\begin{array}{l}\text { 5. State of reward and } \\
\text { incentives }\end{array}$ & $\begin{array}{l}\text { Current reward system should be changed ( } 81 \%) \text {; } \\
\text { Incentive scheme (extrinsic rewards) will boost employee } \\
\text { performance ( } 49 \%) \text {; } \\
\text { Consistent scope of learning (intrinsic rewards) will boost } \\
\text { employee performance (65\%). }\end{array}$ & $\begin{array}{l}\text { Employees do not consider current reward system as a } \\
\text { balanced one; } \\
\text { Employees require balanced reward system as they find } \\
\text { both extrinsic and intrinsic motivation important to } \\
\text { them. }\end{array}$ \\
\hline \multicolumn{3}{|c|}{ Outcome 5: HPWS has a clear strategy of creating balanced reward systems. } \\
\hline $\begin{array}{l}\text { 6. Perceived } \\
\text { significance relevant } \\
\text { training }\end{array}$ & $\begin{array}{l}\text { Regular disaster management training is very important for } \\
\text { APWHS employees (66\%); } \\
\text { Periodic cross-cultural training is needed (60\%). } \\
\text { Employees should update with UNESCO inputs (60\%); } \\
\text { There should be heritage-related programme at APWHS } \\
\text { periodically (51\%). }\end{array}$ & $\begin{array}{l}\text { Employee opinion is forming in favour of appropriate } \\
\text { training; } \\
\text { Employee opinion is forming regarding conforming to } \\
\text { UNESCO standards. } \\
\text { Employee opinion is forming to promote heritage } \\
\text { elements of WHS. }\end{array}$ \\
\hline \multicolumn{3}{|c|}{ Outcome 6: HPWS has a clear strategy of implementing appropriate training to meet the above needs. } \\
\hline $\begin{array}{l}\text { 7. Perceived } \\
\text { significance of } \\
\text { adopting new } \\
\text { marketing policy: }\end{array}$ & $\begin{array}{l}\text { APWHS should launch tourism-related business ( } 83 \%) ; \\
\text { It should run a website and connect to social sites to promote } \\
\text { business ( } 94 \%) ; \\
\text { Online business facility should be there (91\%); }\end{array}$ & $\begin{array}{l}\text { Employees understand the importance of earning ROI; } \\
\text { Employees are keen to use new technology; } \\
\text { Employees are keen to exploit new technology to } \\
\text { enhance ROI. }\end{array}$ \\
\hline \multicolumn{3}{|c|}{ Outcome 7: HPWS has clear provisions to enhance the use of technology. } \\
\hline $\begin{array}{l}\text { 8. Perceived } \\
\text { significance of } \\
\text { knowledge-sharing }\end{array}$ & $\begin{array}{l}\text { APWHS should train and encourage employees to use its internal } \\
\text { web network ( } 71 \%) \text {; } \\
\text { It should increase tourist traffic and other site-related business by } \\
\text { exploiting social networking sites ( } 91 \%) \text {; } \\
\text { It should set an exclusive employee-leaders/managers } \\
\text { communication system on APWHS internal web network ( } 78 \%) \text {. }\end{array}$ & $\begin{array}{l}\text { Clear intention of exploiting new technology; } \\
\text { Clear intention of developing inter-personal } \\
\text { communication; } \\
\text { Clear intention of enhancing communication with } \\
\text { leadership. }\end{array}$ \\
\hline
\end{tabular}


From the above results of the survey mentioned in Table 4. a chart of proponents of HPWS and traditional methods was generated as shown in Figure 4.

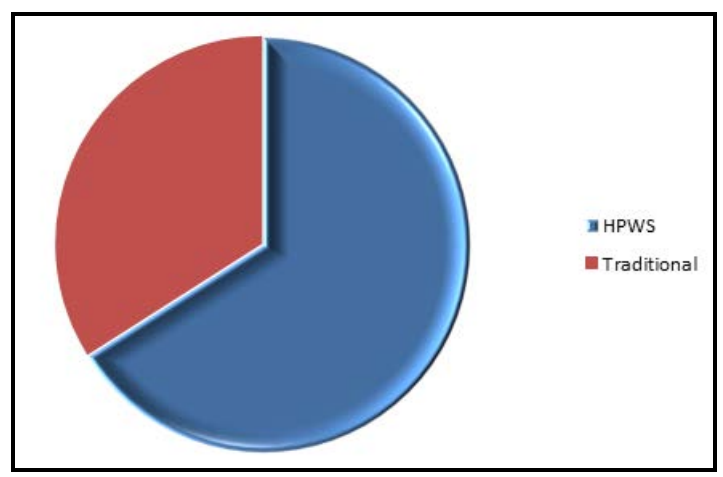

Figure 4. proponents of HPWS and traditional method as per the survey

The results show that most of the interviewees felt that newer methods of work and leadership should be assumed over the traditional methods. These new methods entail HPWS.

The findings of the questionnaire survey in Table 4. clearly highlight several facts. First, it shows that APWHS Management needs some solutions to transform its traditional style of functioning and HPWS has the provisions to provide the same. Second, it shows that there will be no problem in implementing HPWS, since the APWHS employees are ready to accept SHRM. Third, it shows that the current reward system is not balanced in APWHS, and HPWS has the provisions to provide the same.

Fourth, it shows that the APWHS employees are keen on to equip themselves with the help of training. Here too HPWS has provisions to provide the same. Fifth, the employees also showed their keenness to exploit the new technology for the benefit of the organization, which fully aligns with the HPWS's plan to implement new technology. Sixth, the APWHS employees showed high interest in enhancing inter-personal as well as leadermember communication, which fully aligned with HPWS philosophy that aims to make each employee valuable, rare, organized and unparalleled.

\section{Conclusions and Recommendations}

By virtue of the findings of the investigation, this study infers that HPWS is an ideal SHRM application tool for all WHSs, since it is capable of improving the employees' technical expertise, developing team synergy, and transforming them as a committed team that would provide their best to maintain an optimized level of riskpreparedness and exhibit an unflinching attitude to manage any disastrous situation. On the other hand, the study also found that HPWS is capable of enhancing the performance level of the whole team of any WHS management irrespective of their geopolitical, cultural, and socioeconomic origin. Therefore, it can finally be inferred that application of HPWS in all WHSs would definitely help them to conform to the standards set by the UNESCO, and UNESCO, on the other hand, can furthermore evaluate the state of maintenance of all WHSs by applying a common parameter.

\section{References}

[1] UNESCO, (2009). Strengthening Disaster Risk Reduction at World Heritage Properties: the Olympia Protocol for International Cooperation. [online]. Available at

http://www.iaaconservation.org.il/images/files/pdf_docs/Olympia_ Protocol.pdf.

[2] UNESCO. (2012). World heritage list. [Online] Available: http://whc.unesco.org/en/list (January 12, 2011).

[3] Rits-DMUCH. (2012). UNESCO Chair Program on Cultural Heritage and Risk Management International Training Course on Disaster Risk Management of Cultural Heritage 2012. [online]. Available at http://www.ritsumeigcoe.jp/heritagerisknet.dmuch/detail/what/201 203/ITC2012_backgroundandobjective.pdf.

[4] George, P. (2012). Disaster archaeology. [online]. Available at http://www.drgeorgepc.com/DisastersCulturalSites.html.

[5] Wright, P and Guthrie, J. (2005). Labor productivity and HRM. Academy of Management Journal, 46(1), pp. 137-174.

[6] Gardner, T. and Allen, M. (2005). Relationship between worker performance and HR practices. Personnel Psychology, 57: 4, 419416.

[7] Stovel, H. (1998). Risk preparedness: A management manual for World Cultural Heritage. Rome: ICCROM.

[8] Shaw, D and Delery, J. (2001). Research in Personnel and HR management. Greenwich, CT: Jai Press.

[9] Civallero, E. (2008). When Memory Turns into Ashes ... Memoricide During the XX Century. [online]. Available at http://www.libr.org/isc/issues/ISC25/articles/WHEN\%20MEMOR Y\%20TURNS\%20INTO\%20ASHES.pdf.

[10] Chiedozie, A, (2009), The history of Nalanda University. [Online] Available:

http://www.ehow.com/about_5272488_history-nalandauniversity.html (December 3, 2012).

[11] Stovel, H. (1998). Risk preparedness: a management manual for world cultural heritage. [online]. Available at http://www.iccrom.org/pdf/ICCROM_17_RiskPreparedness_en.pd f (January, 27, 2103).

[12] Taboroff, J. (2003). Natural disasters and urban cultural heritage: A reassessment. In Building safer cities: The future of disaster risk. World Bank: Washington, DC. [Online] Available: http://www.preventionweb.net/files/638_868.pdf. ( January 5, 2011).

[13] Erturk, N. (2004). Earthquake preparedness towards cultural heritage losses: The case study of Istanbul museums. In C. Menegazzi (ed.), International Symposium on Cultural Heritage Disaster Preparedness and Response (pp. 243-248). Paris: International Council of Museums (ICOM) Publications.

[14] Grugulis, I. and Marchinton, M. (2000). Best practice management. Journal of Human Resource Management, 11: 6, 1114-1154.

[15] UNESCO / WHC. (2008). Operational guidelines for the implementation of the world heritage convention. Paris: UNESCO World Heritage Centre.

[16] UNESCO / WHC, (2007), Case studies on climate change and world heritage.

[17] Wittemyer, G., Elsen, P., Bean, W.T., Coleman, A., Burton, O. \& Brashares, J.S. (2008). Accelerated human population growth at protected area edges. Science, 321, 123-126.

[18] Paauwe, J. (2004). Achieving long term viability in HRM performance. Oxford, UK: Oxford University Press.

[19] Boxall, P. \& Macky, K. (2007). High-performance work systems and organisational performance: Bridging theory and practice. Asia Pacific Journal of Human Resources, 45(3), 261-270.

[20] Boxall, P. \& Macky, K. (2009). Research and theory on highperformance work systems: progressing the high involvement stream. Human Resource Management Journal, 19(1), 3-23.

[21] Barnes, W. F. (2001). The challenge of implementing and sustaining high performance work system in the United States: An evolutionary analysis of I/N Tek and Kote. Doctoral dissertation: University of Notre Dame.

[22] Ichniowski, C., Kochan, T., Levine, D., Olson, O., \& Strauss, G. (1996). What works at work. Industrial Relations, 35, 299-333.

[23] Applebaum, E., Bailey, T., Berg, P., and Kalleberg, A. (2000). Manufacturing advantage: Why high-performance work systems pay off, Ithaca: ILR Press.

[24] Ichniowski, C., Shaw, K., \& Prennushi, G. (1997) The effects of human resources management practices on productivity: a study of 
steel finishing lines. The American Economic Review, 87(3), 291313.

[25] Huselid, M.A. (1995). The impact of human resource management practices on turnover, productivity, and corporate financial performance. Academy of Management Journal, 38(3), 635-672.

[26] Gardner, J. (1989). On leadership. New York: Free Press.

[27] Goleman, D. (1995). Emotional intelligence. NY: Bantam.

[28] Goleman, D. (1998). Working with emotional intelligence. NY: Bantam.

[29] Owen Jones and the Alhambra, (2012), [Online] Available: http://www.alhambrapatronato.es/index.php/Exhibition/719+M57 28c79703e/0/?\&cHash=57c0703348a63747a1ab8e27159513ec (December 22, 2012).

[30] Hermann, E. D. (1996). Urban Formation and Landscape: Symbol and Agent of Social, Political and Environmental Change
Fourteenth-Century Nasrid Granada. PhD Dissertation, Harvard University.

[31] Irwin, R. (2004). The Alhambra. London: Profile Books. World Cultural Heritage. 22(1).pp. 18-34.

[32] Andreason, A.R. (1996). Profits for nonprofits: Find a corporate partner. Harvard Business Review, 74 (6), 47-69.

[33] Bryman, A., \& Bell, E. (2003).Business Research Methods. Oxford: Oxford.

[34] Al-Zubaidy, Mehdi S. Kaddory; Omer, Spahic; Abdullah, Alias (2012), Exploiting HPWS to Fulfil UNESCO Goals of Preserving and Utilising WHSs FOR THE Benefit of Mankind Part 1, Journal of Knowledge \& Human Resource Management, Vol. 4 Issue 8, p88.

[35] Al-Zubaidy, Mehdi S. Kaddory; Omer, Spahic; Abdullah, Alias (2013), Minimizing Environmental Impact on World Heritage Sites by Exploiting Green Energy, Journal of Global Intelligence \& Policy; Fall2013, Vol. 6 Issue 11, p 141. 